Equilibrium : Jurnal Pendidikan

Vol.IX. Issu 2. Mei-Agustus 2021

\section{Sosiologi}

http://journal.unismuh.ac.id/index.php/equilibrium

\title{
Analisis Keterampilan Menulis Siswa Kelas 1 Pada Model Pembelajaran Daring di SD Muhammadiyah 4 Surabaya
}

\author{
IImi Mustafidhah Rokhimah ${ }^{1}$, Lilik Binti Mirnawati ${ }^{2}$, Fajar Setiawan ${ }^{3}$
}

Fakultas Keguruan dan IImu Pendidikan, Universitas Muhammadiyah Surabaya Email : ilmi.mustafidhah.rokhimah-2019@fkip.um-surabaya.ac.id, Lilikbintimirnawati@fkip.um-surabaya.ac.id, fajarsetiawan@fkip.um-surabaya.ac.id

\begin{abstract}
The purpose of this study was to analyze the writing skills of grade 1 students on the online learning model at SD Muhammadiyah 4 Surabaya. The research method used is descriptive qualitative with the research subjects are 23 students of class 1-A and 1 homeroom teacher of class 1-A at SD Muhammadiyah 4 Surabaya. The data collection techniques used in this study were interviews and documentation. The results of the study based on interviews with homeroom teachers from 1-A stated that the online learning process for low-grade students needed guidance from students' parents or guardians. To minimize parental interference, assignments can be carried out directly during class hours with the risk of requiring longer time because each child has different thinking and writing speeds.Based on the document analysis of student learning outcomes in students' writing skills, the results of the student assessment were the results of the assessment of the overall knowledge of class 1-A students whose success in the assignment reached $90 \%$. While the success in the assessment of student skills as a whole reached $78.8 \%$ with details of every aspect: motor $74 \%$, behavior $78.2 \%$, perception $85 \%$, memory $78.2 \%$. It can be concluded that grade $1-A$ students have mastered initial writing skills.
\end{abstract}

Keywords : Online Learning, Writing Skills.

Abstrak: Tujuan penelitian ini adalah untuk menganalisis keterampilan menulis siswa kelas 1 pada model pembelajaran Daring di Sekolah Dasar Muhammadiyah 4 Surabaya. Metode penelitian yang digunakan adalah kualitatif deskriptif dengan subjek penelitiannya adalah siswa kelas 1-A yang berjumlah 23 siswa dan 1 wali kelas 1-A di Sekolah Dasar Muhammadiyah 4 Surabaya.Teknik pengumpulan data yang digunakan dalam penelitian ini adalah wawancara dan dokumentasi.Hasil penelitian berdasarkan wawancara dengan wali kelas dari 1-A menyatakan bahwa proses pembelajaran secara daring untuk siswa kelas rendah butuh bimbingan dari orang tua atau wali siswa. Untuk meminimalisir adanya campur tangan orang tua, penugasan dapat dikerjakan langsung saat jam pelajaran dengan resiko membutuhkan waktu yang lebih lama dikarenakan setiap anak memiliki kecepatan berfikir dan menulis yang berbeda. Hasil penelitian berdasarkan analisis dokumen hasil belajar siswa yang didapatkan, menunjukkan bahwakeberhasilan penilaian pengetahuan keseluruhan siswa kelas 1-A dalam penugasannya mencapai $90 \%$. Sedangkan keberhasilan dalam penilaian keterampilan siswa secara keseluruhan mencapai $78,8 \%$ dengan perincian setiap aspeknya: motorik $74 \%$, perilaku $78,2 \%$, persepsi $85 \%$, memori $78,2 \%$. Hal ini dapat disimpulkan bahwa siswa kelas 1-A sudah menguasai keterampilan menulis permulaan.

Kata Kunci : Pembelajaran Daring, Keterampilan Menulis. 


\section{PENDAHULUAN}

Pendidikan Sekolah Dasar merupakan pendidikan awal atau dasar dimana anak mulai mengenal pendidikan yang sesungguhnya. Pada tahap pendidikan dasar ini anak mulai mengenal berbagai macam pengetahuan, sikap dan keterampilan. Pembelajaran yang diberikan dimulai dari beberapa mata pelajaran yang harus dikuasai, salah satunya adalah pembelajaran Bahasa Indonesia. Depdiknas (dalam Ambarwati, 2019) memaparkan bahwa pembelajaran Bahasa Indonesia telah diarahkan sejak peserta didik berada di kelas 1 SD dengan tujuan agar peserta didik memiliki kemampuan untuk: 1. Berkomunikasi secara efektif dan efisien sesuai dengan etika yang berlaku, baik secara lisan maupun tulisan; 2 . Menghargai dan bangga menggunakan bahasa Indonesia sebagai bahasa persatuan dan bahasa negara; 3. Memahami Bahasa Indonesia dan menggunakannya dengan tepat dan kreatif untuk berbagai tujuan; 4.Menggunakan Bahasa Indonesia untuk meningkatkan kemampuan intelektual, serta kematangan emosional dan sosial; 5.Menikmati dan memanfaatkan karya sastra untuk memperluas wawasan, memperhalus budi pekerti, serta meningkatkan pengetahuan dan kemampuan berbahasa; 6. Menghargai dan membanggakan sastra Indonesia sebagai khazanah budaya dan intelektual manusia Indonesia sesuai Standar Isi.

Menurut Apri dkk (2018:2), setiap peserta didik dapat dipastikan memiliki kemampuan dasar masing-masing sejak lahir. Kemampuan dasar ini akan tumbuh apabila dibina dan dilatih. Sebaliknya, kemampuan dasar itu menjadi tumpul bila tidak dibina. Dalam belajar bahasa Indonesia, peserta didik memerlukan berbagai keterampilan guna melatih kemampuan dasar yang telah dimilikinya. Terdapat empat keterampilan berbahasa dalam pembelajaran Bahasa Indonesia. Menurut Mirnawati (2019), keterampilan berbahasa Indonesia meliputi empat jenis, yaitu menyimak, berbicara, membaca dan menulis. Menyimak dan membaca merupakan keterampilan berbahasa yang pasif, sedangkan berbicara dan menulis merupakan keterampilan berbahasa yang aktif.Setiap aspek keterampilan memiliki peran penting dalam pembelajaran keterampilan berbahasa, maka dari itu setiap aspek keterampilan harus dikuasai oleh siswa.

Nurgiyantoro (dalam Mirnawati, dkk., 2020) menjelaskan bahwa dibanding ketiga keterampilan lain, keterampilan menulis lebih sulit dikuasai oleh penutur bahasa yang bersangkutan, karena menulis melibatkan berbagai keterampilan yang memerlukan penguasaan unsur kebahasaan, kemampuan menyusun perasaan dan pikiran dengan menggunakan kata-kata dalam bentuk kalimat agar menghasilkan karangan yang runtut dan padu sesuai dengan kaidah-kaidah tata bahasa. Menurut Rinawati (2020) keterampilan menulis menjadi salah satu hal yang harus diajarkan kepada siswa. Di dalam proses pembelajaran keterampilan menulis ini sangat membutuhkan perhatian dari guru dan pihak pengajar, karena keterampilan menulis merupakan salah satu pembelajaran bahasa yang cukup kompleks. Hal ini senada dengan pendapat Bell dan Burnaby (dalam Ghazali, 2013:302), berpendapat bahwa menulis adalah sebuah kegiatan yang sangat kompleks, karena penulis harus mengendalikan bahasa pada level kalimat berdasarkan struktur tata bahasa, kosakata, tanda baca, ejaan dan pembentukan huruf.

Menurut kurikulum 2004 (Meta, 2020:65), standar kompetensi keterampilan menulis di kelas 1 (kelas rendah) diantaranya : 1 . siswa mampu menulis beberapa kalimat yang dibuat sendiri dengan huruf lepas dan huruf sambung, 2. Siswa dapat menulis dikte dari guru, 3. Siswa dapat menulis rapi menggunakan huruf sambung. Standar kompetensi ini diturunkan kedalam tujuh buah kompetensi dasar, yakni: a. membiasakan sikap menulis yang benar (memegang dan menggunakan alat tulis), b. menjiplak dan menebalkan, c. menyalin, d. menulis permulaan, e. menulis beberapa kalimat dengan huruf sambung, f. menulis kalimat yang di dikte guru, g. menulis dengan huruf sambung. Berdasarkan beberapa pendapat yang telah diuraikan, dapat disimpulkan bahwa keterampilan menulis adalah serangkaian kegiatan menuangkan ide, pikiran, gagasan, pendapat maupun perasaannya yang muncul, dengan tujuan agar orang yang membacanya dapat mengetahui apa yang ingin disampaikan penulis. Menurut Lerner (dalam Lestari, 2013:12) menjelaskan bahwa terdapat beberapa faktor permasalahan yang sering dijumpai peserta didik dalam kegiatan menulis, diantaranya:1.Motorik, yakni anak yang perkembangan motoriknya belum matang atau mengalami gangguan sehingga mengalami kesulitan menulis seperti tulisannya tidak jelas atau terputus-putus 
serta tidak mengikuti garis; 2. Perilaku, yakni anak yang hiperaktif atau perhatiaannya mudah teralihkan sehingga dapat menghambat pekerjaan seperti menulis; 3.Persepsi, yakni anak yang terganggu persepsi visualnya akan mengalami kesulitan membedakan beberapa huruf yang hampir sama dan apabila persepsi auditorinya yang terganggu maka ada kemungkinan anak akan mengalami kesulitan dalam menuliskan kata-kata yang diucapkan guru; 4.Memori, yakni anak yang mengalami kesulitan belajar menulis dikarenakan tidak mampu mengingat apa yang akan ditulis. Beberapa faktor penghambat permasalahan siswa dalam menulis tersebut harus diperhatikan dengan baik oleh pendidik untuk mendapatkan cara yang tepat dalam membantu siswa mengembangkan keterampilan menulis yang dimilikinya. Permasalahan mengenai pembelajaran menulis, juga sangat dirasakan oleh peserta didik serta guru khususnya di kondisi wabah pandemic Corona Virus Disease (COVID-19). Sebuah wabah yang merupakan pandemi global sehingga menuntut kementrian pendidikanuntuk melakukan pembelajaran dari rumah (BDR) kepada peserta didik berbasis dalam jaringan (daring) dan luar jaringan (luring).Sesuai denganSurat Edaran Kemendikbud Nomor 4 Tahun 2020 tentang pelaksanaan kebijakan pendidikan dalam masa darurat penyebaran Corona Virus Disease (COVID-19) yang diperkuat dengan SE Sekjen Nomor 15 tahun 2020 mengenai pedoman pelaksaan Belajar Dari Rumah (BDR) selama darurat COVID-19 (Kurniasari, dkk., 2020:1).

Menurut Moore, Dickson-Deane\&Galyen (dalam Sadikin, dkk. 2020), pembelajaran berbasis daring merupakan suatu pembelajaran dengan menggunakan jejaring internet guna memunculkan berbagai jenis interaksi pembelajaran. Pendapat lain mengatakan bahwa penggunaan jejaring internet maupun teknologi multimedia, mampu merubah carapenyampaian pengetahuan siswa dan menjadi alternative pembelajaran yang dilaksanakan selama wabah pandemi COVID-19. Gikas \& Grant (dalam Sadikin, 2020) menjelaskan bahwa pada tahap pelaksanaan pembelajaran daring, sangat diperlukan dukungan perangkat atau media pembelajaran sepertismartphone atau telepon android, laptop, komputer, i-pad atau komputer yang dapat digunakan untuk mengakses informasi kapan saja dan dimana saja. Sedangkan untuk meningkatkan hasil belajar, berbagai macam metode dan media pembelajaran pun telah diterapkan. Sebagai contoh pada pembelajaran daring kelas $1 \mathrm{di}$ SD Muhammadiyah 4,pihak guru mencoba mengajak siswa agar lebih fokus dan semangat belajar walau jarak jauh menggunakan media boneka tangan. Untuk meningkatkan kualitas belajar, guru menggunakan aplikasi zoom, google classroom bahkan menyediakan digital tablets agar memudahkan dalam memberikan penjelasan kepada siswa sebagai pengganti papan tulis.

Dengan adanya perkembangan teknologi yang mencukupi, dalam penerapan pembelajaran dapat berjalan layaknya belajar tatap muka langsung. Namun pada proses pembelajaranyang dirasakan, guru tidak dapat memantau langsung perkembangan siswanya lantaran terdapatbeberapa faktor yang dapat menghambat penilaian guru terhadap setiap siswa maupun pemahaman siswa pada materi yang diberikan guru saat pembelajaran daring. Keterampilan menulis salah satunya, keterampilan terakhir yang didapat dalam keterampilan berbahasa ini menjadi pusat perhatian penulis. Karena pada umumnya, keterampilan menulis dapat berkembang dan dipantau oleh guru seiring waktu ketika pembelajaran tatap muka langsung di sekolah.Akibatnya, dalam pengumpulan tugas mata pelajaran bahasa Indonesia, masih ditemukan beberapa faktor yang mempengaruhi keterampilan menulis siswa antara lain faktor motorik, perilaku, persepsi dan memori. Sebagai contoh, dalam penugasan masih ditemukan adanya huruf yang hilang, adanya huruf yang terbalik, tulisan yang tidak jelas, bahkan adanya anak yang perhatiannya mudah teralihkan sehingga tugas menulis dapat diselesaikan dengan waktu yang cukup lama.

Peneliti pertama, ditulis oleh mahasiswa Pendidikan Guru Sekolah Dasar di Universitas Negri Yogyakarta, dengan judul skripsi "Peningkatan Kemampuan Menulis Permulaan Menggunakan Media Gambar dengan Pendekatan Keterampilan Proses Siswa Kelas 2 SD Malangrejo Kabupaten Sleman". Penelitian tersebut ditulis pada tahun 2013 oleh Ngreni Lestari yang lebih banyak membahas mengenai penggunaan media gambar guna meningkatkan kemampuan menulis permulaan. Dalam penelitian ini, dapat dilihat bahwa terdapat persamaan yakni sama dalam membahas keterampilan menulis permulaan pada obyek yang sama diterapkan pada siswa kelas rendah namun perbedaannya yakni media yang digunakan dalam penelitian serta jenis penelitian 
yang dilakukan berbeda. Peneliti kedua, ditulis oleh mahasiswa fakultas IImu Tarbiyah dan Keguruan Universitas Islam Negri (UIN) Sunan Kalijaga dengan judul skripsi "Studi Analisis Pembelajaran Bahasa Indonesia pada Siswa Berkesulitan Menulis (Dyshgraphia) di SD Intis School Yogyakarta". Penelitian tersebut ditulis pada tahun 2016 olehAninditya Sri Nugraheni dan Rifka Khoirun Nada yang lebih banyak membahas mengenai siswa berkesulitan menulis di sekolah berkebutuhan khusus. Dalam penelitain ini, dapat dilihat bahwa terdapat persamaan yakni jenis penelitian kualitatif deskriptif dengan desain penelitian studi analisis serta memiliki persamaan dalam membahas keterampilan menulis namun perbedaan yang signifikan adalah objek penelitiannya yakni siswa yang diteliti berbeda.

Peneliti ketiga, mahasiswa fakultas Keguruan dan Ilmu Pendidikan (FKIP) di Universitas Jambi dengan judul jurnal "PembelajaranDaring di Tengah Wabah Covid-19". Penelitian tersebut ditulis pada tahun 2020 oleh Ali Sadikin, Afreni Hamidah yang termasuk dalam Jurnal IImiah Pendidikan Biologi.Vol. 06. No 02. Pada penelitian ini titik kesamaannya ada pada model pembelajaran yang dibahas yakni menggunakan model pembelajaran secara dalam jaringan (daring) sedangkan perbedaannya adalah fokus penelitiannya terpusat pada pembelajaran di tengah wabah covid-19 bukan membahas tentang keterampilan menulis. Hasil penelitian dari beberapa penelitian terdahulu di atas mempunyai tujuan untuk mengetahui titik singgung persamaan dan perbedaannya terkait pokok bahasan keterampilan menulis dan pembelajaran daring di tengah wabah Covid-19. Berdasarkan kondisi pembelajaran daring selama pandemi Covid-19 serta kajian dari beberapa teori dan penelitian terdahulu yang telah dibahas, maka tujuan penelitian ini adalah menganalisis keterampilan menulis siswa kelas 1 pada model pembelajaran dalam jaringan (Daring) di SD Muhammadiyah 4 Surabaya.

\section{METODE PENELITIAN}

Penelitian ini menggunakan penelitian kualitatif deskriptif. Menurut Moleong (2016:6) penelitian kualitatif adalah penelitian yang bermaksud untuk memahami fenomena tentang apa yang dialami oleh subjek penelitian misalnya perilaku, persepsi, motivasi, tindakan, dan lain sebagainya secara holistik dan dengan cara deskripsi dalam bentuk kata-kata dan bahasa, pada suatu konteks khusus yang alamiah dan dengan memanfaatkan berbagai metode alamiah. Menurut Miles dan Huberman (dalam Sugiyono,2009:247), terdapat 3 jalur analisis data kualitatif yaitu reduksi data, penyajian data dan penarikan kesimpulan. Teknik penganalisisan data dalam penelitian ini menggunakan tiga teknik yaitu reduksi data, penyajian data dan penarikan kesimpulan dengan bertahap dari data yang diperoleh setelah melaksanakan pengambilan data.

Penelitian ini dilaksanakan pada semester gasal tahun akademik 2020/2021. Subjek penelitian dalam penelitian ini adalah seluruh siswa kelas 1-A di SD Muhammadiyah 4 Surabaya berjumlah 23 siswa yang terdiri dari 12 siswa perempuan dan 11 siswa laki-laki, 1 wali kelas dan wali murid. Seluruh siswa 1-A yang dijadikan sebagai subjek penelitian, akan diambil data keterampilan menulisnya dari hasil penugasan mereka. Wali kelas 1-A yang bekerjasama dengan peneliti akan diambil data dari hasil wawancara. Sedangkan wali murid, menjadi subjek ketiga dalam penguatan data yang telah didapatkan dan dianalisis oleh peneliti.

Teknik pengumpulan data dalam penelitian ini menggunakan triangulasi teknik yakni teknik observasi, wawancara dan dokumentasi. Observasi dilakukan untuk mengetahui proses atau langkah-langkah pembelajaran dimulai dari awal pembelajaran hingga proses pengumpulan data untuk melakukan penilaian keterampilan siswa. Wawancara dilakukan untuk mengetahui data siswa, permasalahan dan metode pengajaran yang biasa dilakukan wali kelas terhadap siswa di masa pandemi Covid-19. Dokumentasi digunakan untuk mengumpulkan dokumen hasil belajar siswa yaitu hasil tulisan atau tugas siswa kelas 1-A yang dikirim melalui grup Whatsapp kepada guru dan foto kegiatan pembelajaran keterampilan menulis secara daring. Langkah-Langkah dalam pengambilan data berupa observasi yakni, diawali dengan pemberian apersepsi pembelajaran sesuai tema yang diajar. Dilanjutkan dengan penyampaian materi dan tanya jawab terkait gambar secara lisan tentang ucapan terima kasih dan permintaan tolong. Selanjutnya, pembelajaran dilanjutkan berupa 
penugasan menulis kepada peserta didik dan hasil tulisan dikirim kepada guru melalui grup whatsapp kelas. Setelah pengumpulan tugas, guru membuat instrument penilaian dan mendata hasil tulisan dari setiap siswa sesuai instrument penilaian yang dicantumkan pada berikut ini.

Instrumen penelitian yang digunakan untuk mengumpulkan data dari teknik wawancara dapat dilihat pada Tabel 1 berikut.

Tabel 1. Kisi-kisi Instrumen Wawancara

\begin{tabular}{cl}
\hline No. & \multicolumn{1}{c}{ Pertanyaan } \\
\hline $\mathbf{1}$ & $\begin{array}{l}\text { Dalam pembelajaran berbasis daring, apakah siswa kelas } 1 \text { dipantau dan dibimbing } \\
\text { orang tua atau pembimbing masing-masing? }\end{array}$ \\
$\mathbf{2}$ & $\begin{array}{l}\text { Mengapa pemberian materi lebih sering diberikan berupa file rangkuman bukan } \\
\text { menulis secara langsung? }\end{array}$ \\
$\mathbf{3}$ & $\begin{array}{l}\text { Kegiatan menulis apa saja yang biasanya dilakukan peserta didik apabila rangkuman, } \\
\text { mengerjakan soal dan ujian berbasis dalam jaringan (Daring)? }\end{array}$ \\
$\mathbf{4}$ & $\begin{array}{l}\text { Apakah lbu pernah memantau hasil tulisan peserta didik atau hanya memberikan } \\
\text { penugasan kepada siswa selama pembelajaran Daring ini? }\end{array}$ \\
$\mathbf{5}$ & $\begin{array}{l}\text { Bagaimana rencana ibu kedepannya selaku wali kelas dalam meningkatkan } \\
\text { keterampilan menulis peserta didik? }\end{array}$ \\
$\mathbf{6}$ & $\begin{array}{l}\text { Bagaimana kita sebagai guru mengetahui dan memantauketika tugas yg diberikan } \\
\text { benar-benar dikerjakan oleh peserta didik bukan orang tua? }\end{array}$ \\
$\mathbf{7}$ & $\begin{array}{l}\text { Bagaimana meminimalisir peserta didik yang lebih dominan tugas sekolah dikerjakan } \\
\text { oleh orang tua? }\end{array}$ \\
$\mathbf{8}$ & $\begin{array}{l}\text { Bagaimana pembelajaran dapat diikuti apabila ada beberapa peserta didik yang } \\
\text { mengalami kesulitan sinyal atau kehabisan paket data? }\end{array}$ \\
$\mathbf{9}$ & $\begin{array}{l}\text { Apakah ada kewajiban dan sanksi tertentu apabila terdapat siswa yg jarang bisa } \\
\text { mengikuti pembelajaran berbasis dalam jaringan (daring)? }\end{array}$ \\
\hline &
\end{tabular}

Instrumen penelitian yang digunakan untuk menganalisis dokumentasi hasil belajar siswa dalam keterampilan menulis selama pembelajaran daring dapat dilihat pada Tabel 2 berikut.

Tabel 2.Kisi-Kisi Penilaian Keterampilan Menulis Siswa

\begin{tabular}{|c|c|c|c|c|c|}
\hline \multirow[t]{2}{*}{ No. } & \multirow[t]{2}{*}{ Kriteria } & \multicolumn{4}{|c|}{ Penilaian } \\
\hline & & Baik Sekali (Skor 4) & Baik (Skor 3) & Cukup (Skor 2) & Kurang (Skor 1) \\
\hline 1 & Motorik & $\begin{array}{l}\text { Tulisan setiap huruf jelas, } \\
\text { tulisan rapi yakni } \\
\text { mengikuti garis atau kotak } \\
\text { pada buku, penulisan per } \\
\text { kata tidak terputus-putus } \\
\text { atau nyambung semua. }\end{array}$ & $\begin{array}{l}\text { Memenuhi } \\
\text { dua criteria }\end{array}$ & $\begin{array}{l}\text { Memenuhi } \\
\text { satu kriteria }\end{array}$ & $\begin{array}{l}\text { Tidak memenuhi } \\
\text { kiteria satu pun }\end{array}$ \\
\hline 2 & Perilaku & $\begin{array}{l}\text { Fokus dengan } \\
\text { pembelajaran (menulis), } \\
\text { tidak mudah teralihkan, } \\
\text { selesai tepat waktu ketika } \\
\text { menulis. }\end{array}$ & $\begin{array}{l}\text { Memenuhi } \\
\text { dua criteria }\end{array}$ & $\begin{array}{l}\text { Memenuhi } \\
\text { satu kriteria }\end{array}$ & $\begin{array}{l}\text { Tidak memenuhi } \\
\text { kriteria satu pun }\end{array}$ \\
\hline 3 & Persepsi & $\begin{array}{l}\text { Tidak ada huruf yang } \\
\text { terbalik contoh (b-d) ( } p \text { - } \\
\text { q), memahami kata- kata } \\
\text { yang diucapkan guru, dan }\end{array}$ & $\begin{array}{l}\text { Memenuhi } \\
\text { dua criteria }\end{array}$ & $\begin{array}{l}\text { Memenuhi } \\
\text { satu kriteria }\end{array}$ & $\begin{array}{l}\text { Tidak memenuhi } \\
\text { kriteria satu pun }\end{array}$ \\
\hline
\end{tabular}




\begin{tabular}{lllll}
\hline 4. Memori & dapat menulisnya. & & \\
& $\begin{array}{l}\text { Dalam penulisan hurufnya } \\
\text { lengkap, mengingat apa } \\
\text { yang akan siswa tulis, } \\
\text { mengingat dalam } \\
\text { penggunaan tanda baca. }\end{array}$ & $\begin{array}{l}\text { Memenuhi } \\
\text { dua criteria }\end{array}$ & $\begin{array}{l}\text { Memenuhi } \\
\text { satu kriteria }\end{array}$ & $\begin{array}{l}\text { Tidak memenuhi } \\
\text { kriteria satu pun }\end{array}$ \\
\end{tabular}

Sumber: (Lestari, 2013:12) dimodifikasi

\section{Keterangan:}

Jumlah nilai 13-16 = Baik Sekali (A)

Jumlah nilai 9-12 = Baik (B)

Jumlah nilai 5-8 = Cukup(C)

Jumlah nilai 1-4 = Kurang (D)

\section{HASIL PENELITIAN DAN PEMBAHASAN}

Hasil penelitian yang didapat dalam penelitian ini dapat dianalisis dari beberapa teknik pengumpulan data, yakni observasi; wawancara; dan dokumentasi. Pada teknik observasi yang diawali dengan penyampaian materi terkait pembuatan kalimat ucapan terima kasih dan kalimat permintaan tolong, dapat diobservasi seberapa besar tingkat pemahaman siswa dalam memahami materi tersebut. Tingkat keberhasilannya, dinilai dari seberapa banyak siswa yang dapat menjawab pertanyaan saat sesi tanya jawab dari peneliti di sela-sela penjelasan terkait pembuatan kalimat. Hasil observasi penelitian ini yakni sebagian siswa dapat menjawab pertanyaan peneliti dengan tepat, sebagian lainnya tidak menjawab lantaran adanya beberapa faktor yang mempengaruhinya, antara lain : 1. adanya siswa yang belum fokus saat peneliti berbicara, 2 . siswa yang tidak mendengar panggilan peneliti saat disuruh menjawab pertanyaan, dan 3 . Adanya siswa yang berkendala sinyal atau jaringan internet saat pembelajaran berlangsung. Namun, beda halnya ketika penugasan diberikan berupa soal dan dijawab secara tertulis dengan waktu yang lebih lama dibandingkan dengan tanya jawab langsung. Berdasarkan data dokumentasi yang telah dikirim melalui grup 'Whatsapp', hasil belajar siswa dalam keterampilan menulis dapat yang ditinjau melalui 4 aspek penilaian ; yakni motorik, perilaku, persepsi dan memori. Adapun hasil dokumentasi dari data yang dapat dianalisis sebagai berikut.

Tabel 3. Hasil Belajar Keterampilan Menulis Siswa

\begin{tabular}{|c|c|c|c|c|c|c|c|}
\hline \multirow[t]{2}{*}{ No. } & \multirow[t]{2}{*}{ Nama Siswa } & \multicolumn{4}{|c|}{ Aspek Penilaian } & \multicolumn{2}{|c|}{ Nilai } \\
\hline & & Motorik & Perilaku & Persepsi & Memori & Jumlah & Ket. \\
\hline 1. & $\mathrm{AAH}$ & 2 & 3 & 4 & 3 & 12 & B \\
\hline 2. & ASG & 3 & 4 & 4 & 3 & 14 & A \\
\hline 3. & ANS & 3 & 3 & 4 & 3 & 13 & A \\
\hline 4. & AVF & 3 & 4 & 4 & 3 & 14 & A \\
\hline 5. & AKH & 4 & 3 & 4 & 4 & 15 & A \\
\hline 6. & ARB & 4 & 4 & 4 & 4 & 16 & A \\
\hline 7. & BAP & 2 & 3 & 4 & 3 & 12 & B \\
\hline 8. & CAM & 3 & 4 & 3 & 3 & 13 & A \\
\hline 9. & CKC & 4 & 3 & 3 & 2 & 12 & B \\
\hline 10. & DAN & 2 & 3 & 4 & 3 & 12 & B \\
\hline 11. & DNS & 4 & 3 & 3 & 4 & 14 & A \\
\hline 12. & $\mathrm{HA}$ & - & - & - & - & - & - \\
\hline
\end{tabular}




\begin{tabular}{cccccccc}
\hline 13. & KRJ & 2 & 2 & 3 & 4 & 11 & B \\
\hline 14. & MRR & 4 & 4 & 4 & 4 & 16 & A \\
\hline 15. & MF & 4 & 4 & 4 & 4 & 16 & A \\
\hline 16. & MIA & 3 & 4 & 3 & 3 & 13 & A \\
\hline 17. & MRA & 4 & 3 & 4 & 4 & 15 & A \\
\hline 18. & MRA & 3 & 4 & 3 & 4 & 14 & A \\
\hline 19. & NTP & 3 & 4 & 4 & 3 & 14 & A \\
\hline 20. & RAF & - & - & - & - & - & - \\
\hline 21. & RZF & 4 & 3 & 4 & 4 & 15 & A \\
\hline 22. & SWJ & 3 & 3 & 4 & 3 & 13 & A \\
\hline 23. & SMAF & 4 & 4 & 4 & 4 & 16 & A \\
\hline
\end{tabular}

\section{a. Aspek Motorik}

Penilaian pada aspek ini terdiri dari beberapa indikator yakni: tulisan setiap huruf jelas, tulisan rapi (mengikuti garis atau kotak pada buku) dan tulisan sesuai per kata (ada spasi). Penilaian keterampilan menulis dalam aspek motorik siswa kelas 1-A sudah mencapai $74 \%$ dari keseluruhan indikatornya. Dengan perincian penilaian sebanyak $39 \%$ atau 9 siswa mendapatkan poin 4 , sebanyak $35 \%$ atau 8 siswa mendapatkan poin 3, dan sebanyak 17,5\% atau 4 siswa mendapatkan poin 2 , sebanyak $8,5 \%$ atau 2 siswa tidak mengumpulkan tugas. Penilaian pada aspek motorik ini perlu menuai perhatian guru maupun wali siswa khususnya pada pembelajaran daring, dikarenakan peneliti masih menemukan siswa yang penulisan hurufnya berdekatan atau tidak ada jarak sehingga sulit untuk menganalisa huruf maupun kata yang ditulis oleh siswa.Selain itu, masih terdapat siswa yang menulis kalimat tanpa adanya spasi antar kata dan tulisannya masih naik turun atau tidak sesuai garis maupun kotak pada buku.

b. Aspek Perilaku

Penilaian pada aspek ini terdiri dari beberapa indikator yakni: fokus dengan pembelajaran (menulis), tidak mudah teralihkan, selesai tepat waktu ketika menulis.Penilaian keterampilan menulis dalam aspekperilaku siswa kelas 1-A sudah mencapai nilai $78,2 \%$ dari keseluruhan indikatornya. Dengan perincian penilaian sebanyak $43,5 \%$ atau 10 siswa mendapatkan poin 4, sebanyak 43,5\% atau 10 siswa mendapatkan poin 3, sebanyak 4,5\% atau 1 siswa mendapatkan poin 2 , dan sebanyak $8,5 \%$ atau 2 siswa tidak mengumpulkan tugas. Tidak hanya pada kelas rendah aspek perilaku ini masih sering dialami siswa dari berbagai macam kelas. Indikator fokus pada pembelajaran menulis dan indikator tidak mudah teralihkan, sering terjadi pada awal pembelajaran daring hingga saat ini.Apabila dikelas, guru akan menegur langsung siswa yang tidak fokus atau teralihkan pada hal lain, sehingga pembelajaran tetap berlanjut dan cepat terselesaikan. Namun pada pembelajaran daring, siswa kelas 1 akan mudah teralihkan dengan lingkungan sekitarnya apabila orang tua tidak mendampingi selama pembelajaran. Maka guru sering memantau dan berdiskusi langsung dengan wali siswa terkait perkembangan pembelajaran siswa selama di rumah agar indikator terakhir yakni dapat menyelesaikan penulisan tepat waktu dapat terlaksana.

Pada penelitian ini, indikator "menyelesaikan tulisan tepat waktu" dinilai dari ketepatan siswa mengumpulkan tugas.Siswa yangmendapatkan poin 4 yakni siswa yang langsung mengumpulkan tugas setelah pembelajaran selesai.Siswa yang mendapatkan poin 3 maupun 2 yakni siswa yang cukup terlambat dalam pengumpulan tugas serta faktor indikator lain selama pembelajaran daring. Di sisi lain, adapula penugasan yang tepat waktu tetapi dikerjakan oleh orang tua siswa, hal ini dapat ditinjau dari penulisan yang berbeda. Hal tersebut agar tidak terulang kembali, guru maupun wali kelas akan sering berkomunikasi dengan orang tua, agar pendidikan anak dapat berkembang walaupun jarak jauh atau melalui pembelajaran daring. 


\section{c. Aspek Persepsi}

Penilaian pada aspek ini terdiri dari beberapa indikator yakni: Tidak ada huruf yang terbalik, contoh (b-d) (p-q), memahami kata - kata yang diucapkan guru, dan dapat menulisnya. Penilaian keterampilan menulis dalam aspek perilaku, siswa kelas $1 \mathrm{~A}$ sudah mencapai $85 \%$ dari keseluruhan indikator nya. Dengan perincian penilaian sebanyak $65,5 \%$ atau 15 siswa mendapatkan poin 4 , sebanyak $26 \%$ atau 6 siswa mendapatkan poin 3, dan sebanyak $8,5 \%$ atau 2 siswa tidak mengumpulkan tugas. Indikator mengenai tulisan yang terbalik, tidak ditemukan pada tugas siswa artinya siswa sudah kelas 1-A sudah bisa membedakan huruf-huruf yang hampir samadan mengetahui perbedaannya. Berikutnya pada indikator memahami kata-kata yang diucapkan guru dan menulisnya yakni dilihat pada pertanyaan secara lisan, sebagian besar siswa sudah bisa menjawab pertanyaan-pertanyaan yang disampaikan, dan menulis jawaban dengan tepat waktu.

\section{d. Aspek Memori}

Penilaian pada aspek ini terdiri dari beberapa indikator yakni : Dalam penulisan hurufnya lengkap, mengingat apa yang akan siswa tulis, mengingat dalam penggunaan tanda baca. Penilaian keterampilan menulis dalam aspek memori, siswa kelas $1 \mathrm{~A}$ sudah mencapai $78,2 \%$ dari keseluruhan indikator nya. Dengan perincian penilaian sebanyak $43,5 \%$ atau 10 siswa mendapatkan poin 4 , sebanyak $43.5 \%$ atau 10 siswa mendapatkan poin 3 , sebanyak $4,5 \%$ atau 1 siswa mendapatkan poin 2 , dan sebanyak $8,5 \%$ atau 2 siswa tidak mengumpulkan tugas. Dalam aspek memori, cukup terlihat fungsi dari pembelajaran keterampilan menulis sejak dini. Pada indikator penulisan huruf, masih terdapat beberapa siswa 1-A yang menulis seusai apa yang ia ucapkan dalam kesehariannya sebagai contoh kata "sudah" yang biasa diucapkan "uda/udah/suda". Adapula siswa yang betul dalam pengucapan namun tidak tau penulisannya dengan tepat seperti kata "mengambilkan" masih ada beberapa siswa yang menulis "meambilkan/menggambilkan". Indikator berikutnya mengenai mengingat apa yang hendak di tulis siswa serta tanda baca. Pada indikator ini, penulis menemukan adanya kesalahan dalam menjawab soal yang seharusnya membuat kalimat "minta tolong kepada ayah" menjadi kalimat "ucapan terima kasih kepada ayah". Sedangkan untuk tanda baca, siswa tidak menuliskan titik di akhir kalimat dan tanda tanya diakhir pada kalimat yang bermakna kalimat tanya.

Selanjutnya yakni hasil wawancara bersama wali kelas 1-A SD Muhammadiyah 4 mengenai keterampilan menulis siswa. Data yang didapatkan dari hasil wawancara dengan wali kelas 1-A yakni Ibu Ika Lukita, S.S. dapat dilihat sebagai berikut.

a. Dalam pembelajaran berbasis daring, apakah siswa kelas 1 dipantau dan dibimbing orang tua atauu pembimbing masing-masing? "Iya, dapat dipastikan setiap siswa dibimbing orang tua atau orang dewasa lain yang ada di rumah, mengingat bahwa tidak semua peserta didik khususnya kelas 1 dapat mengoperasikan gadget seorang diri."

b. Mengapa pemberian materi lebih sering diberikan berupa file rangkuman bukan menulis secara langsung? "Dikarenakan jadwal yang singkat dan target pembelajaran yang cukup banyak, sehingga demi mempersingkat waktu, wali kelas memberikan rangkuman berupa file dan dipelajari bersama orang tua masing-masing siswa."

c. Kegiatan menulis apa saja yang biasanya dilakukan peserta didik apabila rangkuman, mengerjakan soal dan ujian berbasis dalam jaringan (Daring)? "Tidak semua rangkuman maupun tugas pembelajaran dilakukan dengan mengetik, namun ada kalanya siswa diberikan tugas menulis atau tugas-tugas lain seperti membuat poster yang menyangkut kegiatan menulis siswa. Selain itu, soal ujian diberikan berupa file, namun anak diharuskan untuk mencetak (print) dan menjawabnya dengan tulisan."

d. Apakah Ibu pernah memantau hasil tulisan peserta didik atau hanya memberikan penugasan kepaada siswa selama pembelajaran Daring ini? "Pernah, namun kurang efektif dikarenakan dalam pembelajaran, penugasan maupun ketika diadakannya ujian, seharusnya dapat 
memantau hasil tulisan tangan siswa, namun sebagian besar pembelajaran dilakukan secara lisan atau ketikan."

e. Bagaimana rencana ibu kedepannya selaku wali kelas dalam meningkatkan keterampilan menulis peserta didik? "Tetap memberikan latihan menulis, misal memberikan tugas menulis cerita/ puisi/ ucapan untuk orang tua. jangka pendeknya mengajak mereka menulis latihan dan jawaban di buku latihan tematik"

f. Bagaimana kita sebagau guru mengetahui dan memantauketika tugas yg diberikan benar-benar dikerjakan oleh peserta didik bukan orang tua? "Tentunya ini dengan kerja sama orang tua, memang tidak jarang orang tua masih 'tidak tega' kepada anak-anaknya sehingga membantu mengerjakan atau menuliskan. Itulah pentingnya komunikasi antara guru dan wali siswa, menyampaikan jika ke'tidak tega'an itu nantinya akan berakibat tidak baik untuk siswa ke depannya. Jadi saya sering menyampaikan supaya anak-anak mengerjakan sendiri, sebisanya, semampunya, selesai tidak selesai ndak masalah. Dan kita pasti paham benar tulisan anak-anak untuk bisa tahu dibantu atau tidak."

g. Bagaimana meminimalisir peserta didik yang lebih dominan tugas sekolah dikerjakan oleh orang tua? "Tugas dikerjakan langsung saat jam pelajaran, dengan resiko membutuhkan waktu yang lebih lama. Karena tiap anak berbeda kecepatannya. Untuk tugas portofolio memang biasanya saya beri waktu agak lama. untuk kelas bawah memang masih butuh bantuan orang tua, apalagi kondisi daring seperti ini. mau tidak mau membutuhkan kerja sama dengan orang tua."

h. Bagaimana pembelajaran dapat diikuti apabila ada beberapa peserta didik yang mengalami kesulitan sinyal atau kehabisan paket data? "Pendidikan dan pembelajaran arus fleksibel menurut saya, kita sebagai guru harus bisa memahami situasi dan kondisi siswa di rumah (apalagi situasi daring)."

i. Apakah ada kewajiban dan sanksi tertentu apabila terdapat siswa yg jarang bisa mengikuti pembelajaran berbasis dalam jaringan (daring)? "Tidak, Kita tidak bisa memaksakan setiap siswa untuk bisa mengikuti pembelajaran tiap harinya jika memang ada kendala yang dialami siswa di rumah. Terutama di situasi seperti sekarang ini, di mana kendala jaringan, biaya (paketan data), orang tua yang bekerja juga harus menjadi pemikiran kita sebagai guru. Jika ada siswa yang mengalami kendala tersebut, ada baiknya kita sebagai guru memberikan solusi dengan cara mengirimkan file materi ataupun latihan untuk siswa yang bersangkutan. "Menjalin komunikasi yang baik dengan wali siswa supaya kita tahu kendala yang dialami lalu mencari solusi yang terbaik untuk kedua belah pihak. Salah satu cara yang saya ambil, memberikan jeda waktu mengumpulkan tugas selama 1 minggu. Hal tersebut sebagai solusi untuk orang tua yang harus bekerja dan tidak bisa mendampingi atau memantau siswa mengerjakan tugas, karena kelas 1 masih butuh bimbingan dan pendampingan."

Kesimpulan dari data hasil wawancara yang didapatkan yakni setiap proses pembelajaran secara daring untuk siswa kelas rendah butuh bimbingan dari orang tua atau wali siswa. Namun, bukan berarti membantu mengerjakan tugas siswa agar tugas cepat dan tepat dalam penyelesaiannya.Untuk meminimalisir adanya campur tangan orang tua, penugasan dapat dikerjakan langsung saat jam pelajaran dengan resiko membutuhkan waktu yang lebih lama.Karena setiap anak memiliki kecepatan berfikir dan menulis yang berbeda. Terkait permasalahan dalam keterampilan menulis sesuai faktor-faktor penghambatnya yang sering ditemukan, hal tersebut dapat diminimalisir dengan penerapan beberapa kegiatan menulis agar siswa tetap terbiasa layaknya pembelajaran secara tatap muka langsung. Kegiatan-kegiatan tersebut yakni berupa menulis jawaban soal dalam buku tematik, menulis jawaban ujian yang telah di print out atau membuat poster maupun tugas menulis lain disesuaikan dengan pembelajaran atau materi siswa. Selama pembelajaran secara Daring, orang tua atau wali siswa yang mendampingi proses belajar siswa sangat berperan penting. Hal ini ditinjau dari hasil wawancara bersama wali kelas yang menyatakan bahwa wali siswa tidak lepas dalam berkomunikasi dengan wali kelas khususnya terkait penugasan maupun pemberian materi-materi pembelajaran Daring. Komunikasi tersebut tetap 
berjalan sampai saat ini agar orang tua yang mendampingi belajar dapat membantu menjelaskan materi pembelajaran kepada siswa sewaktu waktu. Selain itu, komunikasi dilakukan agar tugas yang diberikan kepada siswa benar-benar dikerjakan oleh siswa bukan orang tua dan dapat dikumpulkan tepat pada waktunya.

\section{KESIMPULAN}

Hasil analisis dalam penelitian pada proses pembelajaran daring di SD Muhammadiyah 4 Surabaya ini menunjukkan bahwa keterampilan menulis permulaan anak memiliki 4 aspek penilaian yakni aspek yakni motorik, perilaku, persepsi dan memori. Selama proses pembelajaran daring, guru dapat mengetahui siswa yang perlu mendapatkan perhatian khusus dalam pembelajaran menulis dan siswa yang sudah cukup menguasai pembelajaran menulis sehingga modul atau penugasan dalam pembelajaran menulis dapat ditingkatkan agar siswa dapat lebih berkembang. Menurut hasil wawancara dengan wali kelas 1-A, menyatakan bahwa proses pembelajaran secara daring untuk siswa kelas rendah butuh bimbingan dari orang tua atau wali siswa. Namun, bukan berarti membantu mengerjakan tugas siswa agar tugas cepat dan tepat dalam penyelesaiannya.Untuk meminimalisir adanya campur tangan orang tua, penugasan dapat dikerjakan langsung saat jam pelajaran dengan resiko membutuhkan waktu yang lebih lama dikarenakan setiap anak memiliki kecepatan berfikir dan menulis yang berbeda.Terkait permasalahan dalam keterampilan menulis sesuai faktor-faktor penghambatnya yang sering ditemukan, hal tersebut dapat diminimalisir dengan penerapan beberapa kegiatan menulis agar siswa tetap terbiasa layaknya pembelajaran secara tatap muka langsung. Kegiatan-kegiatan tersebut yakni berupa menulis jawaban soal dalam buku tematik, menulis jawaban ujian yang telah di print outatau membuat poster maupun tugas menulis lain disesuaikan dengan pembelajaran atau materi siswa. Pada penelitian ini menunjukkan bahwa siswa sudah memahami materi pembuatan kalimat ucapan terima kasih dan permintaan tolong diitinjau dari hasil penilaian pengetahuan keseluruhan siswa 1-A yang keberhasilan dalam penugasannya mencapai $90 \%$. Sedangkan keberhasilan dalam penilaian keterampilan siswa secara keseluruhan mencapai $78,8 \%$ dengan perincian setiap aspeknya: motorik $74 \%$, perilaku $78,2 \%$, persepsi $85 \%$, memori $78,2 \%$. Hal ini dapat menunjukkan bahwa siswa kelas 1-A sudah menguasai keterampilan menulis permulaan dan sudah siap kedepannya secara perlahan untuk mempelajari keterampilan menulis lanjut pada pembelajaran berikutnya.

\section{DAFTAR PUSTAKA}

\section{Sumber Buku}

Apri, Widharyanto, Rishe. 2018. Pembelajaran Bahasa Indonesia untuk SD (Pendekatan dan Teknis). Jakarta : Media Maxima.

Ghazali, Syukur. 2013. Pembelajaran Keterampilan Berbahasa Dengan Pendekatan KomunikatifInteraktif. Bandung: PT. Refika Aditama.

Ginting, Meta Br. 2020. Buku Ajar Bahasa Indonesia Sekolah Dasar Kelas Rendah. Klaten : Lakeisha. Moleong, Lexy J. 2016. Metodologi Penelitian Kualitatif(Cet ke-35). Bandung: Remadja Rosdakarya. . 2017. Kementerian Pendidikan dan Kebudayaan. Keluargaku. Jakarta : Kementerian Pendidikan dan Kebudayaan.

\section{Sumber Jurnal/Prosiding}

Ambarwati,Wahyu. 2019.Tarling: Journal of Language Education. Peningkatan Keterampilan Membaca Pemahaman Melalui Metode SQ3R di SDN 01 Pajerukan.Vol.2 No. 1.

Kurniasari, Asrilia., dkk. 2020. Jurnal Review Pendidikan Dasar: Jurnal Kajian Pendidikan dah Hasil Penelitian. Analisis Efektivitas Pelaksanaan Belajar Dari Rumah (BDR) Selama Pandemi Covid19. Vol.6, No.3, September 2020. 
Mirnawati, Lilik Binti. 2019. Jurnal Belajar Bahasa. Keefektifan Model Pembelajaran Inovatif dengan Menggunakan Mind Mapping Dalam Pembelajaran menulis Narasi Siswa SD. Vol. 4 No. 1 Februari. Jember:Universitas Muhammadiyah Jember.

Mirnawati, Lilik Binti., dkk. 2020. Proceedings Conference of Elementary Studies 2020. Proses Pengembangan Model Pembelajaran Inovatif Dengan Menggunakan Mind Mapping Dalam Pembelajaran Menulis Narasi Di SD. Surabaya:Universitas Muhammadiyah Surabaya.

Rinawati, Agustin., dkk. 2020. Analisis Hubungan Keterampilan membaca Dengan Keterampilan Menulis Siswa Sekolah Dasar. Vol.4 No.2 Agustus. Jember: LPPM IKIP PGRI Jember.

Sadikin, Ali.,\& Hamidah, Afrendi.2020. Jurnal Ilmiah Pendidikan Biologi. PembelajaranDaring di Tengah Wabah Covid-19.Vol. 06. No 02.Jambi.

\section{Sumber Skripsi}

Lestari, Ngreni. 2013. Peningkatan Kemampuan Menulis Permulaan Menggunakan Media Gambar dengan Pendekatan Keterampilan Proses Siswa Kelas 2 Malangrejo Kabupaten Sleman.(eprints.uny.ac.id). Yogyakarta.Universitas Negri Yogyakarta.

Nugraheni, Aninditya Sri dan Rifka Khoirun Nada. 2016. "Studi Analisis Pembelajaran Bahasa Indonesia pada Siswa Berkesulitan Menulis (Dyshgraphia) di SD Intis School Yogyakarta". Yogyakarta.Universitas Islam Negri (UIN) Sunan Kalijaga. 